\title{
The capabilities of secondary school teachers to provide financial education ${ }^{1}$
}

\author{
Kenneth De Beckker ${ }^{\mathrm{a} 2}$, Boukje Compen ${ }^{\mathrm{ab}}$, Dirk De Bock ${ }^{\mathrm{a}}$, and Wouter Schelfhout ${ }^{\mathrm{c}}$ \\ aLeuven Economics of Education Research (LEER), Faculty of Economics and Business, KU Leuven, Belgium. \\ ${ }^{b}$ Department of Training and Education Sciences, Faculty of Social Sciences, University of Antwerp, Belgium. \\ ${ }^{c}$ Antwerp School of Education, Faculty of Social Sciences, University of Antwerp, Belgium.
}

3 April 2019

\begin{abstract}
This study examines the capabilities of in-service secondary school teachers to provide financial education. Data was gathered from online surveys which were spread among 300 teachers in the Flemish region of Belgium. We distinguish between perceived and actual capabilities. Our results reveal that only one third of teachers considers themselves sufficiently competent to provide financial education. Actual capabilities are assessed using a broad measure of financial literacy which takes into account teachers' financial knowledge, financial behaviour and financial attitudes. Our results indicate that only approximately half of teachers score sufficiently on financial knowledge and only a third attains the preferred minimum score for financial attitudes. In addition, our heterogeneity analysis shows differences in scores related to teacher characteristics such as gender, teaching discipline, and teaching experience. The large share of teachers not reaching the threshold indicating adequate capabilities for providing financial education raises concern, as teacher quality is an important factor contributing to the effectiveness of financial education. Teacher professional development can play a crucial role here.
\end{abstract}

Keywords: financial knowledge, financial behaviour, financial attitudes, financial education, teacher professional development

\footnotetext{
${ }^{1}$ The authors would like to thank Evelyn Bijnens and Geert Van Campenhout for their help to contact the participants and proofreading the survey. For insightful comments and suggestions, we thank Vanessa Naegels.

This work was supported by Wikifin.be, the financial literacy program of the Financial Services and Markets Authority (FSMA), and by the Research Foundation Flanders (FWO) through the programme 'Financial Literacy @ School' (grant number S000617N).

${ }^{2}$ Corresponding author info: Kenneth De Beckker, Leuven Economics of Education Research (LEER), Faculty of Economics and Business, KU Leuven, Naamsestraat 69, 3000 Leuven, Belgium.

Email: kenneth.debeckker@kuleuven.be
} 


\section{Introduction}

The ability to make well-informed financial decisions is a critical $21^{\text {st }}$ century life skill. Due to changes in, for example, retirement provision, and the growing complexity of financial markets and products, individuals are becoming increasingly responsible for their own financial well-being (Aprea et al., 2016). These trends, combined with insights demonstrating significant room for improvement regarding the financial literacy of both adults and youth around the world (OECD, 2016a, 2017), have led governmental bodies to develop policies aiming to raise financial literacy levels (OECD 2016a). Most of these focus on integrating financial education in school curricula (Fox et al., 2005). ${ }^{3}$

As interest in financial education programmes increases, so does the amount of studies discussing the effectiveness of these programmes (e.g. Asarta et al., 2014; Batty et al., 2015; Fan and Chatterjee, 2018; Xiao and O'Neill, 2016). A majority of these studies focus on evaluating student outcomes (McCormick, 2009; Sasser and Grimes, 2010). In contrast, little is known on the capabilities of the teachers participating in these programmes. However, the literature provides evidence that teacher quality plays a central role in student performance (e.g. Stronge et al., 2011) and influences student learning to a larger extent than any other objective school variable (Goldhaber, 2002; Hanushek, 2011). So despite the recognition that well-trained teachers are considered as crucial for the effectiveness of financial education (Consumer Financial Protection Bureau, 2013; Totenhagen et al., 2015; Van Campenhout et al., 2017), there is only limited evidence available on teachers' financial literacy.

In this paper, we examine whether in-service secondary school teachers are sufficiently financially literate to provide financial education. To this end, we spread online surveys among a sample of 300 teachers in Flanders, the Dutch-speaking region of Belgium. While previous research focuses either on measuring teachers' self-perceived competences to teach financial topics (Sawatzki and Sullivan, 2017; Way and Holden, 2009), or exclusively measures teachers' financial knowledge (Otter, 2010); we follow De

\footnotetext{
${ }^{3}$ For an overview of financial education programmes for children and adolescents see Amagir et al. (2018).
} 
Moor and Verschetze (2017) in taking a more comprehensive approach by additionally assessing teachers' financial behaviour and attitudes. In addition, we assess which teacher characteristics influence financial literacy, and to what extent teachers perceive themselves competent to provide financial education. While De Moor and Verschetze (2017) focus on pre-service teachers (i.e. students in teacher education), we examine the financial literacy of in-service teachers. As Flanders is reforming the educational system and introducing the obligation for schools to provide financial education, it is particularly relevant to investigate whether current teachers are sufficiently financially literate, or whether professional development would be required.

\section{Literature review}

\section{Financial literacy}

Along with the increased interest in financial literacy, a multitude of definitions have been proposed. Both Remund (2010) and Huston (2010) reviewed the literature to establish common ground regarding the conceptualisation and operationalization of financial literacy. Huston (2010) concluded that, in correspondence with general literacy, financial literacy has two main dimensions: understanding (financial knowledge) and application (the appropriate use of this knowledge).

Remund (2010) evaluated different definitions used in the literature and reveals that these dimensions of understanding and application can be further categorised as follows: (1) knowledge of financial concepts, (2) the ability to communicate about these concepts, (3) the ability to manage personal finances, (4) the skills to make well-informed financial choices, and (5) the confidence to plan for future financial needs. The definition developed by PISA, which is often referred to, largely reflects these five categories:

"Financial literacy refers to the knowledge and understanding of financial concepts and risks, and the skills, motivation and confidence to apply such knowledge and understanding in order to make effective decisions across a range of financial contexts, 
to improve the financial well-being of individuals and society, and to enable participation in economic life." (OECD, 2017, 50)

The fact that equating financial literacy with financial knowledge is insufficient, is also reflected in the operationalization used in recent OECD studies (e.g. OECD, 2016b). In these studies, financial literacy levels are not only assessed by items measuring financial knowledge, but also by items examining financial behaviour and attitudes. This allows to determine whether a participant has a sufficient understanding of financial topics, and if this understanding consequently results in appropriate application.

\section{The importance of financial education for young people}

Many strategies striving to enhance the population's financial literacy focus on educating youth. A major benefit of integrating financial education in school curricula is the potential to reach all students. Irrespective of their socioeconomic background, students get equal opportunities to develop financially desirable behaviour (Van Campenhout et al., 2017). Reviewing the literature on financial literacy sheds light on why financial education could be beneficial for youth in both the short- and the long-term.

The current generation of youth increasingly faces complex financial decisions, tasks and responsibilities, such as managing student loans and credit card debts (Lusardi et al., 2010). As financial mistakes at a young age may snowball into larger problems later in life, the provision of financial education at school may be a strategy to prevent youth from making these mistakes (Lusardi et al., 2010). This is confirmed by several studies demonstrating that financial education has a positive impact on financial knowledge and behaviour, even years later. Brown et al. (2016) reveal that financial literacy training at high school reduces the likelihood of having debts a decade later. This is a promising finding, especially when considering that outstanding debts are the greatest financial concern during early adulthood (Brown et al., 2016). Peng et al. (2007) examine the longterm effect of financial education on investment knowledge. Results indicate that alumni who followed a personal finance course, have higher levels of investment knowledge. Finally, Xiao and O'Neill (2016) show that individuals who received financial education, 
score higher on financial literacy, and are more likely to demonstrate desirable financial behaviour, such as saving.

\section{The role of teachers in financial education}

High quality teachers are considered to be a prerequisite for effective financial education, and a variety of factors have been shown to contribute to this quality. First, teachers need to feel confident about their capability to provide financial education, as teacher efficacy in general has been shown to have a positive effect on aspects such as teachers' instructional behaviour and student achievement (Haynes and Chinadle 2007; TschannenMoran and Hoy, 2001). Second, teachers must be sufficiently financially literate themselves to provide their students with high quality financial education (De Moor and Verschetze, 2017). Finally, it seems plausible that factors such as teaching discipline and years of teaching experience may influence teachers' (perceived) competences regarding the provision of financial education (Way and Holden, 2009).

A few studies examined teachers' attitudes towards, and beliefs about, financial education (e.g. De Moor and Verschetze, 2017; Neill et al., 2014; Otter, 2010; Sawatzki and Sullivan, 2017; Way and Holden, 2009). While almost all teachers in these studies acknowledge the importance of financial literacy at school, only a selection consider themselves capable to teach financial topics. Sawatzki and Sullivan (2017) assess the selfperceived competences of Australian primary school teachers and show that while more than $75 \%$ consider themselves financially literate, only $50 \%$ feel confident to provide financial education. Way and Holden (2009) reveal that on average, $61 \%$ of the $\mathrm{K}-12$ teachers in the United States consider themselves capable to teach financial matters. This percentage drops to $47 \%$ when more technical aspects such as risk management or insurance are concerned.

While Sawatzki and Sullivan (2017) and Way and Holden (2009) rely on measures of self-perceived competence, other researchers test teachers' financial literacy in an objective manner. Otter (2010) reveals an average knowledge score of $37.5 \%$ on a personal finance questionnaire, indicating that teachers lack the subject matter 
knowledge that is required for providing financial education. Furthermore, Loibl (2008) shows that irrespective of teaching discipline (business education, family and consumer sciences, social studies, or science), teachers' average knowledge test score is lower than $50 \%$. The approach of De Moor and Verschetze (2017) to test the financial literacy of (preservice) teachers is innovative in two ways. First, they go beyond measuring financial knowledge by additionally examining teachers' financial behaviour and attitudes. They argue that teachers' adequate financial behaviour and attitudes are essential to set an example for students. Second, the authors introduce a minimum level of financial literacy that teachers should reach, i.e. a particular threshold to be considered capable to provide financial education. This implies that a distinction could be made between being financially literate, and being sufficiently financial literate to teach financial topics. Their results indicate that only $16 \%$ of the pre-service teachers reach the threshold of $75 \%$.

To our knowledge, the comprehensive approach of De Moor and Verschetze (2017) has not yet been used to examine in-service teachers. This study aims to fill this gap in the literature by spreading an online survey measuring financial knowledge, behaviour, and attitudes among in-service teachers in Flanders. In addition, we examine to what extent teacher characteristics influence these financial literacy scores, and ask teachers to indicate their self-perceived competence to provide financial education.

Based on the discussion above, we aim to answer the following research questions:

RQ1: Do in-service secondary school teachers feel competent to teach students about financial topics?

RQ2: Are in-service secondary school teachers sufficiently financially literate to be capable to provide financial education? Which teacher characteristics influence teachers' financial literacy levels? 


\section{Method}

\section{Research context}

In this study we focus on in-service secondary teachers in Flanders, the Dutch-speaking region of Belgium. Students in the Flemish secondary education system are usually between 12 and 18 years old, and follow one out of three tracks: general secondary education, technical secondary education, or vocational secondary education. The six secondary school years are divided into three stages, each lasting two years.

In general secondary education students attend broad, non-specific courses which prepare them for higher education. Technical secondary education combines general education with more technical subjects. After technical secondary education, the students may practice a profession or attend a university college. This track also includes practical training. In vocational secondary education the focus lies on learning a profession.

The research context of Flanders is of particular interest as from school year 20192020 onwards, the educational system will be reformed. In particular, schools are then obliged to ensure that students eventually master a set of basic competences - among which financial literacy - that allow them to fully participate in society (Ministerie van Onderwijs en Vorming, 2017). Since no specific requirements related to financial literacy were included in the curriculum before this educational reform, the majority of current in-service secondary school teachers has not received training to provide financial education. Therefore, we assess whether in-service teachers in Flanders are capable to teach their students about financial topics, or whether some form of professional development would be required.

\section{Sample}

Data for this study was collected via an online survey. The survey gathers information related to teachers' profiles (e.g. years of teaching experience, discipline) and their capabilities to provide financial education. We initially distributed 1,615 surveys, of which 
490 were returned. The 300 surveys without any missing data were eventually included in the study. All in-service secondary school teachers could participate, independent of aspects such as teaching discipline. We apply sampling weights to the data to ensure our sample is representative in terms of teacher and school specific characteristics in Flanders.

Table 1 reports the sample characteristics. Our weighted sample contained more female (68.05\%) than male teachers (31.95\%). Most of the teachers in our sample have a Bachelor degree $(55.15 \%)$ as the highest attained level of education, the remainder a Master degree (44.85\%). Since teaching discipline may influence a teacher's financial literacy level, we made a distinction between economics (31.80\%) and non-economics teachers (68.20\%). The years of teaching experience may play a role in whether a teacher feels confident to teach financial topics. The majority of teachers in our sample has less than 20 years of experience (68.16\%), the remainder has 21 - 30 years (16.91\%) or 31 - 40 years of experience (14.93\%). Teachers were also asked to indicate in which educational track they usually teach: general secondary education (42.05\%), technical secondary education $(31.80 \%)$, or vocational secondary education (26.15\%). Finally, we asked teachers whether they work in a public (36.37\%) or a private school (63.63\%). 
Table 1. Sample characteristics $(N=300)$.

\begin{tabular}{lc}
\hline & $\%$ \\
\hline Gender & \\
Male & $31.95 \%$ \\
Female & $68.05 \%$ \\
Education teacher & \\
Bachelor & $55.15 \%$ \\
Master & $44.85 \%$ \\
Discipline & \\
Non-economics teacher & $68.20 \%$ \\
Economics teacher & $31.80 \%$ \\
Teaching experience & \\
$1-10$ years & $36.05 \%$ \\
$11-20$ years & $32.11 \%$ \\
$21-30$ years & $16.91 \%$ \\
31-40 years & $14.93 \%$ \\
Educational track & \\
General secondary education & $42.05 \%$ \\
Technical secondary education & $31.80 \%$ \\
Vocational secondary education & $26.15 \%$ \\
Type of school & \\
Public & \\
Private & $36.37 \%$ \\
\hline
\end{tabular}

Note: Data are weighted to be representative in terms of teacher and school specific characteristics in Flanders.

\section{Measurements}

We measure teachers' perceived competence by asking them to respond to the question: "How competent do you consider yourself in providing financial education?". Responses were indicated on a five-point Likert scale ranging from $1=$ totally incompetent to $5=$ very competent. Teachers' actual competence to provide financial education is captured by measuring their personal financial literacy level. To measure financial literacy, we follow the approach of the OECD (2015), which defines financial literacy as a combination of financial knowledge, financial behaviour and financial attitudes ${ }^{4}$. Financial knowledge is measured through nine questions covering the following themes: simple and compound interest, inflation, time-value of money, stocks, bonds, investment products, risk and

\footnotetext{
${ }^{4}$ Appendix A provides a detailed overview of the test items and the calculation of the three different scores. Appendix B reports the percentage of teachers with a correct or desirable answer for each test item of the three domains.
} 
return, and the relation between bond prices and interest rates. The questions originate from OECD (2015), Lusardi and Mitchell (2011) and van Rooij et al. (2012). Every correct answer is attributed a value of one. The final score is measured as the number of correct responses to the financial knowledge questions, rescaled to 100.

Financial behaviour is measured through questions that examine how teachers deal with money in their daily lives. Four behavioural items were included: considering a purchase, paying bills on time, responsible budget behaviour, and shopping around before making a financial decision. The questions assessing the financial behaviour of teachers are derived from the survey of the OECD toolkit for measuring financial literacy (2015). The response to every item is scored with a one if it reflects desirable financial behaviour, and with a zero otherwise. The financial behaviour score is measured as the sum of the number of desirable financial behaviours, rescaled to 100 .

Teachers' financial attitudes are evaluated using three statements which measure teachers' beliefs regarding planning, saving for the future, and spending. The statements are designed to capture attitudes towards the long-term, and answered using a 5-point Likert-scale. The statements are derived from the OECD (2015). The financial attitude score is measured as the average sum of the values for the three statements, rescaled to 100.

\section{Analysis}

To determine whether or not an individual teacher is capable of providing financial education, we consult his/her scores on all financial literacy domains (financial knowledge, financial behaviour and financial attitudes). To get an overview of the financial literacy in the full sample, we compute the mean score of all teachers for each domain. In addition, we examine the scores among subsamples of teachers, created on the basis of teacher and school characteristics. In correspondence with De Moor and Verschetze (2017), we calculate the proportion of teachers scoring above the $75 \%$ (sufficient score) and 85\% (excellent score) thresholds. To test whether the means of subsamples are significantly different from each other we use a one-way analysis of 
variance (ANOVA) analysis. In addition, we run ordinary least squares (OLS) regression analyses to determine which teacher and school characteristics are correlated with scores on each of the financial literacy domains.

\section{Results}

\section{Teachers' perceived capabilities to provide financial education}

As previous studies argued that teachers' effectiveness in providing financial education may be influenced by their perceived capability to teach financial topics (e.g. Way and Holden, 2009), we start our results section with some descriptive statistics on how teachers perceive their capability to provide financial education. Table 2 reports that only $34 \%$ of the teachers consider themselves competent enough to provide financial education.

Table 2. Teachers' perceived capabilities to provide financial education

\begin{tabular}{llllll}
\hline & $\begin{array}{l}\text { Totally } \\
\text { incompetent }\end{array}$ & $\begin{array}{l}\text { Somewhat } \\
\text { incompetent }\end{array}$ & Neutral & $\begin{array}{l}\text { Adequately } \\
\text { competent }\end{array}$ & $\begin{array}{l}\text { Very } \\
\text { competent }\end{array}$ \\
\hline $\begin{array}{l}\text { How } \\
\text { competent do }\end{array}$ & 21.53 & 17.33 & 27.59 & 28.77 & 4.79 \\
$\begin{array}{l}\text { you consider } \\
\text { yourself in }\end{array}$ & & & & & \\
$\begin{array}{l}\text { providing } \\
\text { financial }\end{array}$ & & & & & \\
education? & & & & & \\
\hline
\end{tabular}

Note: All numbers in this table are percentages. Data are weighted to be representative in terms of teacher and school specific characteristics in Flanders.

\section{Teachers' actual capabilities to provide financial education}

As the next step in our analysis we investigate whether teachers score sufficiently high on financial knowledge, financial behaviour, and financial attitudes to be considered capable to provide financial education. The results are presented in Table 3. Panel A reports the results on financial knowledge, panel $B$ those on financial behaviour, and panel $C$ those on financial attitudes. The first column of each panel presents the full sample's average score, the second and third column present the percentage shares of respondents scoring higher than the $75 \%$ and $85 \%$ thresholds, respectively. These thresholds indicate whether 
a teacher has a sufficient or an excellent score on financial knowledge, financial behaviour and financial attitudes. In accordance with De Moor and Verzetsche (2017) we consider the $75 \%$ threshold as the minimum level for being able to teach financial topics.

The average score of the participating teachers is approximately $70 \%$ on financial knowledge, $76 \%$ on financial behaviour, and $68 \%$ on financial attitudes. This implies that the average teacher scores less than the minimum level for two out of the three financial literacy domains. In contrast to financial behaviour for which $87 \%$ of the teachers score sufficiently, only $51 \%$ of the teachers score sufficiently on financial knowledge and only $30 \%$ on financial attitudes. In addition, only a minority of teachers have excellent scores on financial knowledge (29\%), financial behaviour (19\%) and financial attitudes (12\%).

The next rows in Table 3 report teachers' financial literacy scores split by teachers' gender, educational background, teaching discipline, teaching experience, educational track and type of school. We use the F-statistic from the ANOVA to test whether the differences between the subgroups are significant. The results indicate that males tend to have higher financial knowledge scores than females. The reverse is true for financial attitudes, where women tend to outperform men. The highest attained level of education significantly impacts the financial knowledge score, but does not influence financial behaviour or financial attitudes. Considering teaching disciplines, we observe that on average, teachers whose main subject is related to economics, score higher on financial knowledge than those who teach other subjects. The effect of discipline on financial behaviour is less outspoken, and for financial attitudes, the difference between economics and non-economics teachers is not significant. Despite the fact that economics teachers tend to perform better, the share of those with an excellent score is still relatively small: $56 \%$ of the teachers score excellent on financial knowledge, $21 \%$ on financial behaviour, and $11 \%$ on financial attitudes. Teaching experience also seems to have a positive effect on financial knowledge. For the two other financial literacy components, the relation is less clear-cut. We further notice a difference between the average financial knowledge score of teachers in general or technical education and those 
teaching in vocational education. The last group of teachers scored significantly lower than the other two groups. Regarding the type of school, we observe that teachers in private schools have higher average scores on financial knowledge and financial attitudes than teachers in public schools. 
Table 3. Performance on each financial literacy domain.

\begin{tabular}{|c|c|c|c|c|c|c|c|c|c|}
\hline & \multicolumn{3}{|c|}{ Panel A: Financial knowledge } & \multicolumn{3}{|c|}{ Panel B: Financial behaviour } & \multicolumn{3}{|c|}{ Panel C: Financial attitudes } \\
\hline & $\begin{array}{l}\text { Mean } \\
\text { score }\end{array}$ & $\begin{array}{l}\text { Sufficient } \\
(>75)\end{array}$ & $\begin{array}{l}\text { Excellent } \\
(>85)\end{array}$ & Mean score & $\begin{array}{l}\text { Sufficient } \\
(>75)\end{array}$ & $\begin{array}{l}\text { Excellent } \\
(>85)\end{array}$ & $\begin{array}{l}\text { Mean } \\
\text { score }\end{array}$ & $\begin{array}{l}\text { Sufficient } \\
(>75)\end{array}$ & $\begin{array}{l}\text { Excellent } \\
(>85)\end{array}$ \\
\hline Total sample & 69.92 & $50.65 \%$ & $29.25 \%$ & 76.40 & $87.04 \%$ & $19.43 \%$ & 68.25 & $29.75 \%$ & $11.75 \%$ \\
\hline \multicolumn{10}{|l|}{ Gender } \\
\hline Male & 76.45 & $62.47 \%$ & $40.81 \%$ & 76.38 & $83.64 \%$ & $24.33 \%$ & 65.71 & $23.70 \%$ & $9.28 \%$ \\
\hline Female & 66.86 & $45.11 \%$ & $23.83 \%$ & 76.41 & $88.63 \%$ & $17.12 \%$ & 69.44 & $32.59 \%$ & $12.91 \%$ \\
\hline F-statistic & $15.35 * * *$ & $8.02 * *$ & $9.31 * *$ & 0.00 & 1.44 & 2.17 & $4.39 *$ & 2.47 & 0.83 \\
\hline \multicolumn{10}{|l|}{ Education teacher } \\
\hline Bachelor & 62.50 & $35.01 \%$ & $15.14 \%$ & 76.51 & $87.21 \%$ & $19.82 \%$ & 66.78 & $31.07 \%$ & $11.05 \%$ \\
\hline Master & 79.06 & $69.89 \%$ & $46.61 \%$ & 76.27 & $86.83 \%$ & $18.94 \%$ & 70.04 & $28.12 \%$ & $12.61 \%$ \\
\hline F-statistic & $59.27 * * *$ & $40.79 * * *$ & $40.00 * *$ & 0.02 & 0.01 & 0.04 & $3.81 *$ & 0.31 & 0.17 \\
\hline \multicolumn{10}{|l|}{ Discipline } \\
\hline Non-economics teacher & 63.23 & $37.14 \%$ & $16.93 \%$ & 75.14 & $83.10 \%$ & $18.69 \%$ & 67.69 & $28.95 \%$ & $11.92 \%$ \\
\hline Economics teacher & 84.27 & $79.63 \%$ & $55.68 \%$ & 79.12 & $95.48 \%$ & $21.00 \%$ & 69.44 & $31.45 \%$ & $11.39 \%$ \\
\hline F-statistic & $91.51 * * *$ & $55.37 * * *$ & $55.65^{* * *}$ & $4.81 *$ & $9.05 * *$ & 0.22 & 0.96 & 2.38 & 0.02 \\
\hline \multicolumn{10}{|l|}{ Teaching experience } \\
\hline 1-10 years & 64.91 & $42.23 \%$ & $20.09 \%$ & 79.37 & $87.72 \%$ & $29.96 \%$ & 65.66 & $24.46 \%$ & $4.74 \%$ \\
\hline $11-20$ years & 70.12 & $51.27 \%$ & $35.02 \%$ & 73.86 & $82.39 \%$ & $15.48 \%$ & 68.26 & $25.66 \%$ & $14.02 \%$ \\
\hline $21-30$ years & 73.75 & $58.37 \%$ & $33.47 \%$ & 77.16 & $93.85 \%$ & $14.79 \%$ & 71.17 & $43.01 \%$ & $19.48 \%$ \\
\hline $31-40$ years & 77.27 & $60.92 \%$ & $34.22 \%$ & 73.85 & $87.66 \%$ & $7.73 \%$ & 71.15 & $36.28 \%$ & $15.04 \%$ \\
\hline F-statistic & $4.97 * * *$ & 2.07 & $7.64 * * *$ & $2.97^{*}$ & 1.33 & 4.55 & 2.49 & 2.50 & $3.05^{*}$ \\
\hline \multicolumn{10}{|l|}{ Educational track } \\
\hline General Secondary Education & 73.36 & $57.98 \%$ & $34.44 \%$ & 74.34 & $82.84 \%$ & $16.52 \%$ & 70.45 & $37.78 \%$ & $16.44 \%$ \\
\hline Technical Secondary Education & 74.13 & $55.99 \%$ & $36.27 \%$ & 77.58 & $88.90 \%$ & $21.44 \%$ & 67.79 & $21.66 \%$ & $10.10 \%$ \\
\hline Vocational Secondary Education & 59.28 & $32.39 \%$ & $12.39 \%$ & 78.29 & $91.52 \%$ & $21.66 \%$ & 65.25 & $26.65 \%$ & $6.21 \%$ \\
\hline F-statistic & $16.20 * * *$ & $7.41 * * *$ & 2.33 & 2.21 & 1.00 & 0.58 & $5.13^{* *}$ & $3.67 *$ & 2.64 \\
\hline \multicolumn{10}{|l|}{ Type of school } \\
\hline Public & 62.03 & $38.40 \%$ & $17.96 \%$ & 77.26 & $82.71 \%$ & $27.85 \%$ & 65.67 & $28.34 \%$ & $13.42 \%$ \\
\hline Private & 74.44 & $57.65 \%$ & $35.71 \%$ & 75.91 & $89.51 \%$ & $14.61 \%$ & 69.71 & $30.55 \%$ & $10.80 \%$ \\
\hline F-statistic & $28.47 * * *$ & $10.59 * * *$ & $10.88^{* * *}$ & 0.58 & 2.86 & $7.92 * *$ & $5.52 *$ & 0.16 & 0.46 \\
\hline
\end{tabular}




\section{Teachers characteristics influencing financial literacy}

Lastly, we examine whether the influence of the teacher (and school) characteristics on the three financial literacy scores remains significant after simultaneously controlling for all other variables. Table 4 therefore presents the results of the OLS regressions with the scores on each financial literacy component as the outcome variables, and gender, educational background, discipline, teaching experience, educational track, and type of school as the predictors ${ }^{5}$. We find that gender differences are only statistically significant in the knowledge and attitudes components: compared to their female colleagues, male teachers score, on average, 8.38 points more on knowledge and 4.29 points less on attitudes. With regard to the educational level of teachers, findings indicate that, ceteris paribus, a Master degree results in a knowledge score that is 7.98 points higher. Regarding the disciplines of teachers, we find that economics teachers score, on average, 16.17 points higher on knowledge than non-economics teachers. Moreover, being an economics teacher has a positive influence on financial behaviour: economics teachers score, ceteris paribus, 5.18 points higher than non-economics teachers. With respect to years of teaching experience we notice that the knowledge score tends to increase with experience up till 30 years. For financial behaviour we find some evidence that the least experienced teachers have the highest scores. The financial attitude score is highest for teachers having 21 to 30 years of experience. We also find that teachers in vocational education, on average, score significantly lower than teachers whose main teaching responsibilities are situated in general secondary education (5.97 points lower on knowledge and 4.19 on financial attitudes). Finally, we observe some differences in teachers' financial knowledge according to school type. Teachers working in private schools seem to be more financial knowledgeable compared to those active in public education (6.86 points higher).

\footnotetext{
${ }^{5}$ The coefficients of the regressions may be interpreted as percentage points since we rescaled our outcome variables to 100 .
} 
Table 4. Multivariate analysis of financial literacy

\begin{tabular}{|c|c|c|c|}
\hline & $\begin{array}{l}\text { Financial } \\
\text { knowledge }\end{array}$ & Financial behaviour & Financial attitudes \\
\hline Gender: Male & $\begin{array}{l}8.380^{* * *} \\
(1.995)\end{array}$ & $\begin{array}{l}0.418 \\
(1.843)\end{array}$ & $\begin{array}{l}-4.293 * * \\
(1.796)\end{array}$ \\
\hline Education teacher: Master & $\begin{array}{l}7.984^{* * *} \\
(2.144)\end{array}$ & $\begin{array}{l}-1.659 \\
(1.981)\end{array}$ & $\begin{array}{l}1.972 \\
(1.930)\end{array}$ \\
\hline Discipline: Economics teacher & $\begin{array}{l}16.17^{* * *} \\
(2.149)\end{array}$ & $\begin{array}{l}5.177^{* * *} \\
(1.985)\end{array}$ & $\begin{array}{l}-0.049 \\
(1.935)\end{array}$ \\
\hline \multicolumn{4}{|l|}{$\begin{array}{l}\text { Teaching experience (base group: 1- } \\
10 \text { year) }\end{array}$} \\
\hline $11-20$ year & $\begin{array}{l}3.988^{*} \\
(2.203)\end{array}$ & $\begin{array}{l}-5.695^{* * *} \\
(2.036)\end{array}$ & $\begin{array}{l}2.762 \\
(1.984)\end{array}$ \\
\hline 21-30 year & $\begin{array}{l}6.152^{* *} \\
(2.747)\end{array}$ & $\begin{array}{l}-3.614 \\
(2.538)\end{array}$ & $\begin{array}{l}5.568^{* *} \\
(2.473)\end{array}$ \\
\hline $31-40$ year & $\begin{array}{l}6.661^{* *} \\
(2.838)\end{array}$ & $\begin{array}{l}-5.916^{* *} \\
(2.622)\end{array}$ & $\begin{array}{l}4.337^{*} \\
(2.556)\end{array}$ \\
\hline \multicolumn{4}{|l|}{$\begin{array}{l}\text { Educational track (base group: } \\
\text { General secondary education) }\end{array}$} \\
\hline Technical secondary education & $\begin{array}{l}-0.0945 \\
(2.181)\end{array}$ & $\begin{array}{l}3.311 \\
(2.015)\end{array}$ & $\begin{array}{l}-2.869 \\
(1.964)\end{array}$ \\
\hline Vocational secondary education & $\begin{array}{l}-5.968^{* *} \\
(2.495)\end{array}$ & $\begin{array}{l}3.310 \\
(2.305)\end{array}$ & $\begin{array}{l}-4.191^{*} \\
(2.247)\end{array}$ \\
\hline Type of school: Private & $\begin{array}{l}6.864 * * * \\
(2.003)\end{array}$ & $\begin{array}{l}-0.157 \\
(1.850)\end{array}$ & $\begin{array}{l}2.644 \\
(1.803)\end{array}$ \\
\hline Constant & $\begin{array}{l}52.43^{* * *} \\
(2.587)\end{array}$ & $\begin{array}{l}76.87^{* * *} \\
(2.390)\end{array}$ & $\begin{array}{l}66.60 * * * \\
(2.329)\end{array}$ \\
\hline Observations & 300 & 300 & 300 \\
\hline R-squared & 0.420 & 0.064 & 0.076 \\
\hline
\end{tabular}

Note: Standard errors in parentheses. ${ }^{* * *} p \leq 0.01,{ }^{* *} p \leq 0.05,{ }^{*} p \leq 0.1$

\section{Discussion and conclusion}

In this paper we examine whether in-service secondary school teachers in Flanders are well prepared to provide financial education. Our results reveal that only approximately one third of the teachers perceive themselves competent enough to provide financial education. Considering their actual capabilities, we notice that approximately half of the teachers reach the minimum threshold that indicates sufficient financial knowledge for providing financial education, and that only one third show the financial attitudes considered as adequate. Flemish teachers have more favourable scores in the domain of financial behaviour, with almost 4 out of 5 teachers reaching the preferred minimum. The results additionally indicate heterogeneous effects. In particular, 
the financial knowledge score tends to be higher for teachers who are male, are higher educated, have more teaching experience, and work on private schools. Teacher characteristics seem to be less influential in the financial behaviour and financial attitudes domains. Most important to note is that economics teachers generally perform better on financial behaviour and that female teachers tend to score better on financial attitudes.

With financial education gradually becoming part of school curricula worldwide, it is problematic that teachers' perceived and actual competences to provide financial education are lacking. Since teacher quality is one of the most important determinants of effective financial education (e.g. Van Campenhout et al., 2017), incapable teachers reduce the likelihood that financial education programmes become successful. Therefore, our conclusion implies a need for teacher professional development (TPD). The aim of TPD initiatives is to positively impact the quality of teachers such that their teaching practices are changed and student learning is enhanced (Collinson et al., 2009; Desimone, 2009).

Previous studies demonstrate the feasibility of TPD within the financial literacy context. Many teachers seem to be willing to engage in TPD initiatives (Neill et al., 2014; Sawatzki and Sullivan, 2017). Furthermore, even short initiatives can have a positive impact on student performance, which implies cost effectiveness (Swinton et al., 2007). However, while a significant number of studies evaluating financial education programmes integrate some form of TPD (e.g. Asarta et al., 2014; Batty et al., 2015), these studies rarely assess its impact separately. As a result, it remains unclear how TPD initiatives should be shaped to optimize its potentially beneficial effects (Compen et al., 2019). Considering that financial education is often integrated in school curricula nationwide (OECD, 2016a), future research is particularly recommended to evaluate TPD forms that allow for large-scale implementation, such as online teacher professional development (Dede et al., 2009).

A few limitations of our study are noteworthy. First, as the participating teachers responded to an open call, our sample is unlikely to be free from selection bias. 
Potentially, mainly teachers with a particular interest in financial education filled in the survey. As a result, we are unable to claim that our sample is representative for the entire teacher population in Flanders. Second, while the survey results provide us with relevant insights regarding the financial literacy levels of teachers, it would have been informative to gain a deeper understanding of the exact needs of teachers that should be fulfilled to become and feel capable to teach about financial topics. A suggestion for future research is therefore to collect qualitative data that could be useful when designing teacher professional development. 


\section{Appendix A}

Financial knowledge score

The financial knowledge score is measured as the number of correct responses to the financial knowledge questions in Table A1, rescaled to 100.

Table A1. Construction of financial knowledge score

\begin{tabular}{|c|c|c|c|c|}
\hline Topic & Question & & ssible responses & $\begin{array}{l}\text { Value towards } \\
\text { final score }\end{array}$ \\
\hline Simple interest & $\begin{array}{l}\text { Suppose you put } € 100 \text { into a } \\
\text { savings account and interest } \\
\text { rate was } 2 \% \text { per year. How } \\
\text { much would be in the account } \\
\text { at the end of the first year? }\end{array}$ & $\begin{array}{l}\text { a) } \\
\text { b) } \\
\text { c) } \\
\text { d) }\end{array}$ & $\begin{array}{l}€ 102 \\
€ 112 \\
€ 120 \\
\text { Don't know }\end{array}$ & $\begin{array}{l}1 \text { for correct } \\
\text { responses, } 0 \\
\text { in all other } \\
\text { cases }\end{array}$ \\
\hline Compound interest & $\begin{array}{l}\text { Suppose you put } € 100 \text { into a } \\
\text { savings account and interest } \\
\text { rate was } 2 \% \text { per year. How } \\
\text { much would be in the account } \\
\text { at the end of the fifth year? }\end{array}$ & $\begin{array}{l}\text { a) } \\
\text { b) } \\
\text { c) } \\
\text { d) }\end{array}$ & $\begin{array}{l}\text { Less than } € 110 \\
\text { Exactly } € 110 \\
\text { More than } € 110 \\
\text { Don't know }\end{array}$ & $\begin{array}{l}1 \text { for correct } \\
\text { responses, } 0 \\
\text { in all other } \\
\text { cases }\end{array}$ \\
\hline Inflation & $\begin{array}{l}\text { Imagine that the interest rate } \\
\text { on your savings account was } 1 \% \\
\text { per year and inflation was } 2 \% \\
\text { per year. After one year, how } \\
\text { much would you be able to buy } \\
\text { with the money in this account? }\end{array}$ & $\begin{array}{l}\text { a) } \\
\text { b) } \\
\text { c) } \\
\text { d) }\end{array}$ & $\begin{array}{l}\text { More than today } \\
\text { Exactly the same } \\
\text { Less than today } \\
\text { Don't know }\end{array}$ & $\begin{array}{l}1 \text { for correct } \\
\text { responses, } 0 \\
\text { in all other } \\
\text { cases }\end{array}$ \\
\hline Time value of money & $\begin{array}{l}\text { Assume a friend inherits } \\
€ 10,000 \text { today and his sibling } \\
\text { inherits } € 10,000 \text { three years } \\
\text { from now. Who is richer } \\
\text { because of the inheritance? }\end{array}$ & $\begin{array}{l}\text { a) } \\
\text { b) } \\
\text { c) } \\
\text { d) }\end{array}$ & $\begin{array}{l}\text { My friend } \\
\text { His sibling } \\
\text { They are equally } \\
\text { rich } \\
\text { Don't know }\end{array}$ & $\begin{array}{l}1 \text { for correct } \\
\text { responses, } 0 \\
\text { in all other } \\
\text { cases }\end{array}$ \\
\hline Definition of stocks & $\begin{array}{l}\text { What happens if somebody } \\
\text { buys the stock of a firm B in the } \\
\text { stock market? }\end{array}$ & $\begin{array}{l}\text { a) } \\
\text { b) } \\
\text { c) }\end{array}$ & $\begin{array}{l}\text { He owns a part of } \\
\text { firm B } \\
\text { He has lent money } \\
\text { to firm B } \\
\text { He is liable for firm } \\
\text { B debt }\end{array}$ & $\begin{array}{l}1 \text { for correct } \\
\text { responses, } 0 \\
\text { in all other } \\
\text { cases }\end{array}$ \\
\hline
\end{tabular}




\begin{tabular}{|c|c|c|c|c|}
\hline \multirow[t]{3}{*}{ Definition of bonds } & What is a bond? & b) & $\begin{array}{l}\text { A bond is a part of } \\
\text { the capital of a } \\
\text { company } \\
\text { A bond is a part of } \\
\text { a loan that is } \\
\text { issued by a } \\
\text { company or by a } \\
\text { government }\end{array}$ & \multirow[t]{3}{*}{$\begin{array}{l}1 \text { for correct } \\
\text { responses, } 0 \\
\text { in all other } \\
\text { cases }\end{array}$} \\
\hline & & c) & $\begin{array}{l}\text { A bond is a part of } \\
\text { an investment } \\
\text { fund. }\end{array}$ & \\
\hline & & d) & Don't know & \\
\hline Investment products & $\begin{array}{l}\text { A 'tak } 21 \text { ' insurance compared } \\
\text { with a 'tak } 23 \text { ' insurance seems: }\end{array}$ & $\begin{array}{l}\text { a) } \\
\text { b) } \\
\text { c) } \\
\text { d) }\end{array}$ & $\begin{array}{l}\text { More risky } \\
\text { Equally risky } \\
\text { Less risky } \\
\text { Don't know }\end{array}$ & $\begin{array}{l}1 \text { for correct } \\
\text { responses, } 0 \\
\text { in all other } \\
\text { cases }\end{array}$ \\
\hline Concept of risk & $\begin{array}{l}\text { Suppose that an investor } \\
\text { spreads his money among } \\
\text { different assets instead of one. } \\
\text { What happens with the risk of } \\
\text { losing money? }\end{array}$ & $\begin{array}{l}\text { a) } \\
\text { b) } \\
\text { c) } \\
\text { d) }\end{array}$ & $\begin{array}{l}\text { It increases } \\
\text { It decreases } \\
\text { It stays the same } \\
\text { Don't know }\end{array}$ & $\begin{array}{l}1 \text { for correct } \\
\text { responses, } 0 \\
\text { in all other } \\
\text { cases }\end{array}$ \\
\hline Effect interest on bonds & $\begin{array}{l}\text { If the interest rate falls, what } \\
\text { should happen to bond prices? }\end{array}$ & $\begin{array}{l}\text { a) } \\
\text { b) } \\
\text { c) } \\
\text { d) }\end{array}$ & $\begin{array}{l}\text { Rise } \\
\text { Fall } \\
\text { Stay the same } \\
\text { Don't know }\end{array}$ & $\begin{array}{l}1 \text { for correct } \\
\text { responses, } 0 \\
\text { in all other } \\
\text { cases }\end{array}$ \\
\hline
\end{tabular}

Note: Questions are derived from OECD (2015), Lusardi and Mitchell (2011) and van Rooij et al. (2012), with the exception of the question on investment products, which is of particular relevance for the Flemish context. Correct answers are in bold. 


\section{Financial behaviour score}

The financial behaviour score is measured as the sum of the number of desirable financial behaviours mentioned in Table A2, rescaled to 100 .

Table A2. Construction of financial behaviour score

\begin{tabular}{|c|c|c|c|}
\hline Topic & Question & Possible responses & $\begin{array}{l}\text { Value towards } \\
\text { final score }\end{array}$ \\
\hline Considered purchase & $\begin{array}{l}\text { I carefully consider whether I } \\
\text { can afford it when making the } \\
\text { decision to buy something. }\end{array}$ & $\begin{array}{l}\text { To what extent do you } \\
\text { agree with this } \\
\text { statement? } 5 \text { point } \\
\text { Likert-scale with } 1 \text { = } \\
\text { completely disagree, } 2 \\
\text { disagree, } 3 \text { = neutral, } 4 \\
=\text { agree, and } 5 \\
\text { completely agree. }\end{array}$ & $\begin{array}{l}1 \text { point for } \\
\text { respondents } \\
\text { who put } \\
\text { themselves at } 4 \\
\text { or } 5 \text { on the } \\
\text { scale. } 0 \text { in all } \\
\text { other cases. }\end{array}$ \\
\hline Timely bill payment & I pay my bills on time & $\begin{array}{l}\text { To what extent do you } \\
\text { agree with this } \\
\text { statement? } 5 \text { point } \\
\text { Likert-scale with } 1 \text { = } \\
\text { completely disagree, } 2 \\
\text { disagree, } 3 \text { = neutral, } 4 \\
=\text { agree, and } 5 \\
\text { completely agree. }\end{array}$ & $\begin{array}{l}1 \text { point for } \\
\text { respondents } \\
\text { who put } \\
\text { themselves at } 4 \\
\text { or } 5 \text { on the } \\
\text { scale. } 0 \text { in all } \\
\text { other cases. }\end{array}$ \\
\hline \multirow[t]{2}{*}{ Responsible budget } & $\begin{array}{l}\text { Who is responsible for making } \\
\text { day-to-day decisions about } \\
\text { money in your household? }\end{array}$ & $\begin{array}{l}\text { a) I make these } \\
\text { decisions by } \\
\text { myself } \\
\text { b) My life partner } \\
\text { makes the } \\
\text { financial decisions } \\
\text { c) I do it together } \\
\text { with my partner } \\
\text { d) Someone else } \\
\text { makes the } \\
\text { financial decisions }\end{array}$ & $\begin{array}{l}1 \text { point if } \\
\text { personally or } \\
\text { jointly } \\
\text { responsible for } \\
\text { money } \\
\text { management } \\
\text { AND household } \\
\text { has a budget. } 0 \\
\text { in all other } \\
\text { cases. }\end{array}$ \\
\hline & $\begin{array}{l}\text { Does your household has a } \\
\text { budget? }\end{array}$ & $\begin{array}{l}\text { a) Yes } \\
\text { b) No }\end{array}$ & \\
\hline Tried to shop around & $\begin{array}{l}\text { Which of the following } \\
\text { statements best describes how } \\
\text { you made your last choice with } \\
\text { respect to the purchase of a } \\
\text { financial product? }\end{array}$ & $\begin{array}{l}\text { a) considered } \\
\text { several options } \\
\text { from different } \\
\text { companies before }\end{array}$ & $\begin{array}{l}1 \text { point for } \\
\text { respondents } \\
\text { who chose } \\
\text { option a. } 0 \text { in } \\
\text { all other cases. }\end{array}$ \\
\hline
\end{tabular}


making my

decision

b) I considered the

various options

from one

company

c) I didn't consider any other options at all.

d) I looked around but there were no other options to consider

Note: The questions are derived from OECD (2015) 


\section{Financial attitude score}

The financial attitude score is measured as the average sum of the values for the three statements reported in Table A3 and then rescaled to 100.

Table A3. Construction of financial attitude score

\begin{tabular}{ll}
\hline Statement & Possible responses \\
\hline I tend to live for today and let tomorrow take care of itself & \\
$\begin{array}{l}\text { I find it more satisfying to spend money than to save it for } \\
\text { the long term. }\end{array}$ & $\begin{array}{l}\text { To what extent do you agree with this } \\
\text { statement? } 5 \text { point Likert-scale with } 1= \\
\text { completely agree, } 2 \text { agree, } 3=\text { neutral, } 4 \\
=\text { disagree, and } 5 \text { completely disagree. }\end{array}$ \\
Money is there to be spent & \\
\hline
\end{tabular}

Note: The questions are derived from OECD (2015) 


\section{Appendix B}

\section{Table B1. Components of financial literacy}

Panel A: Correct answers to financial knowledge questions

\begin{tabular}{ll}
\hline Simple interest & 97.37 \\
Compound interest & 82.32 \\
Inflation & 84.65 \\
Time value of money & 67.73 \\
Definition of stocks & 86.13 \\
Definition of bonds & 66.31 \\
Investment products & 38.66 \\
Risk and return & 79.66 \\
Effect interest on bonds & 26.50 \\
\hline
\end{tabular}

Panel B: Desirable financial behaviours

Considered purchase

Timely bill payment

Responsible budget

Tried to shop around

Panel C: Desirable financial attitudes

\subsection{7}

93.53

$\begin{array}{lc}\text { Planning } & 64.71 \\ \text { Saving for the future } & 56.28 \\ \text { Spending } & 26.62\end{array}$

Note: All numbers in this table represent percentages. Panel A reports the percentage of teachers answering each financial knowledge question correctly. Panel B reports the percentage of teachers with a desirable response on each item examining financial behaviour. Panel $\mathrm{C}$ reports the percentage of teachers with a desirable response to each of the statements examining financial attitudes. The data are weighted to be representative in terms of teacher and school specific characteristics in Flanders. 


\section{References}

Amagir A, Groot W, Maassen van den Brink H, et al. (2018) A review of financial-literacy education programs for children and adolescents. Citizenship, Social \& Economics Education 17(1): 56-80.

Aprea C, Wuttke E, Breuer K, et al. (2016) Financial literacy in the twenty-first century: An introduction to the international handbook of financial literacy. In: Aprea CE, Wuttke K, Breuer NK, et al. (eds) International Handbook of Financial Literacy. Singapore: Springer, pp. 1-4.

Asarta CJ, Hill AT and Meszaros BT (2014) The features and effectiveness of the Keys to Financial Success curriculum. International Review of Economics Education 16: 3950.

Batty M, Collins JM and Odders-White E (2015) Experimental evidence on the effects of financial Education on Elementary School Students' Knowledge, Behavior, and Attitudes. Journal of Consumer Affairs 49(1): 69-96.

Brown M, Grigsby J, Van Der Klaauw W, et al. (2016) Financial education and the debt behavior of the young. Review of Financial Studies 29(9): 2490-2522.

Chetty R, Friedman JN and Rockoff JE (2014) Measuring the impacts of teachers II: Teacher value added and student outcomes in adulthood. American Economic Review 104(9): 2633-2679.

Collinson V, Kozina E, Kate Lin YH, et al. (2009) Professional development for teachers: A world of change. European Journal of Teacher Education 32(1): 3-19.

Compen B, De Witte K and Schelfhout W (2019) The role of teacher professional development in financial literacy education: A systematic literature review. Educational Research Review 26: 16-31. 
Consumer Financial Protection Bureau (2013) Transforming the financial lives of a generation of young americans: Policy recommendations for advancing $K-12$ financial education. Washington, DC.

De Moor L and Verschetze L (2017) Student teachers' capacity and willingness to teach financial literacy in flanders. Journal of Financial Counseling and Planning 28(2), 313-321.

Dede C, Ketelhut DJ, Whitehouse $P$, et al. (2009) A research agenda for online teacher professional development. Journal of Teacher Education 60(1): 8-19.

Desimone LM (2009) Improving impact studies of teachers' professional development: Toward better conceptualizations and measures. Educational Researcher 38(3): 181-199.

Fan $L$ and Chatterjee S (2018) Application of situational stimuli for examining the effectiveness of financial education: A behavioral finance perspective. Journal of Behavioral and Experimental Finance 17: 68-75.

Fox, J, Bartholomae S and Lee J (2005) Building the case for financial education. Journal of Consumer Affairs 39(1): 195-214.

Goldhaber D (2002) The mystery of good teaching. Education Next 2(1): 50-55.

Hanushek EA. (2011) The economic value of higher teacher quality. Economics of Education Review 30(3): 466-479.

Haynes DC and Chinadle N (2007) Private sector/educator collaboration: Project improves financial, economic literacy of America's youth. Journal of Family and Consumer Sciences 99(1): 8-10.

Huston SJ (2010) Measuring financial literacy The Journal of Consumer Affairs 44(2): 296-316. 
Loibl C (2008) Survey of financial education in Ohio's schools: Assessment of teachers, programs, and legislative efforts. Report, the Ohio State University, USA, April.

Lusardi A and Mitchell OS (2011) Financial literacy around the world: an overview. Journal of Pension Economics \& Finance 10(4): 497-508.

Lusardi A, Mitchell OS and Curto V (2010) Financial literacy among the young. Journal of Consumer Affairs 44(2): 358-380.

McCormick MH (2009) The effectiveness of youth financial education: A review of the literature. Journal of Financial Counseling and Planning 20: 70-84.

Ministerie van Onderwijs en Vorming (2017) Modernisering secundair onderwijs en nieuwe eindtermen in laatste rechte lijn. Available at https://onderwijs.vlaanderen.be/nl/modernisering-secundair-onderwijs-en-nieuweeindtermen-in-laatste-rechte-lijn (accessed 26 April 2018).

Neill A, Berg M and Stevens L (2014) Financial literacy of secondary students, and its place within secondary schools. Report, New Zealand Council for Educational Research, New Zealand.

OECD (2015) 2015 OECD/INFE Toolkit for measuring financial literacy and financial inclusion. Paris: OECD Publishing.

OECD (2016a) Financial education in Europe: Trends and recent developments. Paris: OECD Publishing.

OECD (2016b) OECD/INFE International survey of adult financial literacy competencies. Paris: OECD Publishing.

OECD (2017) PISA 2015 Results (Volume IV): Students' financial literacy. Paris: OECD Publishing. 
Otter D (2010) Teaching financial literacy in K-12 Schools: A survey of teacher beliefs and knowledge. PhD Thesis, The University of New Mexico, USA.

Peng TCM, Bartholomae S, Fox JJ, et al. (2007) The impact of personal finance education delivered in high school and college courses. Journal of Family and Economic Issues 28(2): 265-284.

Remund DL (2010) Financial literacy explicated: The case for a clearer definition in an increasingly complex economy. Journal of Consumer Affairs 44(2): 276-295.

Sasser SL and Grimes PW (2010) Personal financial literacy: A baseline analysis of teacher knowledge in Oklahoma. Franklin Business and Law Review Journal 3: 6882.

Sawatzki CM and Sullivan PA (2017) Teachers' perceptions of financial literacy and the implications for professional learning. Australian Journal of Teacher Education 42(5): 51-65.

Stronge JH, Ward TJ and Grant LW (2011) What makes good teachers good?: A crosscase analysis of the connection between teacher effectiveness and student achievement. Journal of Teacher Education 62(4): 339-355.

Swinton JR, De Berry TW, Scafidi B, et al. (2007) The impact of financial education workshops for teachers on students' economic achievement. The Journal of Consumer Education 24: 63-77.

Totenhagen CJ, Casper DM, Faber KM, et al. (2015) Youth financial literacy: A review of key considerations and promising delivery methods. Journal of Family and Economic Issues 36(2): 167-191.

Tschannen-Moran M, and A Woolfolk Hoy (2001) Teacher efficacy : Capturing an elusive construct. Teaching and Teacher Education 17: 783-805. 
Van Campenhout G, De Witte K and De Beckker K (2017) Financiële vorming op school. In: De Witte K and Hindriks J (eds) De Geslaagde School. Brussels: Itinera Institute, pp. 153-182.

van Rooij M, Lusardi A and Alessie R (2012) Financial literacy, retirement planning, and household wealth. The Economic Journal 122(560): 449-478.

Way WL and Holden KC (2009) Teachers' background and capacity to teach personal finance: Results of a national study. Journal of Financial Counseling and Planning 20(2): 64-78.

Xiao JJ and O’Neill B (2016) Consumer financial education and financial capability. International Journal of Consumer Studies 40(6): 712-721. 